\title{
Ideology, Critique and Surveillance
}

\author{
Heidi Herzogenrath-Amelung
}

\author{
University of Westminster. hherzogenrath@gmail.com
}

\begin{abstract}
The 2013 revelations concerning global surveillance programmes demonstrate in unprecedented clarity the need for Critical Theory of information and communication technologies (ICTs) to address the mechanisms and implications of increasingly global, ubiquitous surveillance. This is all the more urgent because of the dominance of the "surveillance ideology" (the promise of security through surveillance) that supports the political economy of surveillance. This paper asks which theoretical arguments and concepts can be useful for philosophically grounding a critique of this surveillance ideology. It begins by examining how the surveillance ideology works through language and introduces the concept of the 'ideological packaging' of ICTs to show how rhetoric surrounding the implementation of surveillance technologies reinforces the surveillance ideology. It then raises the problem of how ideology-critique can work if it relies on language itself and argues that Martin Heidegger's philosophy can make a useful contribution to existing critical approaches to language.
\end{abstract}

Keywords: Critical Theory, Heidegger, ICTs, surveillance, ideology, critique, language

Acknowledgement: I would like to acknowledge the helpful criticism of Paul Taylor, Pete Goodwin, Pinelopi Troullinou and Graham Creeth.

\section{Introduction: The Surveillance Ideology}

Earlier this year Edward Snowden, a former employee of the American intelligence services CIA and NSA, leaked details of the US electronic surveillance programme "PRISM" 1 to a number of newspapers. The leaks revealed the full extent of US surveillance operations, and triggered the exposure of similar programmes in the United Kingdom (Tempora) used to spy on the electronic communications of ordinary citizens. Critical approaches to ICTs have drawn attention to the fact that these programmes are not an anomalous event, a singular storm in otherwise calm waters (Fuchs 2013), as some of the vehement reactions in the media and amongst public figures might suggest. The truth is that they form part of a more general trend towards "ubiquitous surveillance" (Murakami Wood 2011) that has been going on for some time. Even more crucially, critical theorists have been calling into question the arguments used to justify this increasingly global and ubiquitous surveillance, namely that programmes such as PRISM and Tempora are "absolutely essential for effective fighting of terrorism" (Former Home Secretary John Reid cited in Watson 2013). As Christian Fuchs (2013) has argued, "[s]ince 9/11 there has been an intensification and extension of surveillance that is based on the naïve technological-deterministic surveillance ideology that monitoring technologies, big data analysis and predictive algorithms can prevent terrorism".

Doubts are regularly voiced as to how effective these forms of surveillance are in combatting terrorism and lowering crime ${ }^{2}$. So we are right to ask how the surveillance ideology, which we can define broadly as the promise of security through surveillance, maintains itself. The possibility explored in this paper is that the large-scale surveillance programmes re-

\footnotetext{
1 Whilst writing this paper, details of an even more comprehensive NSA surveillance operation, called "XKeyscore", were revealed. It purports to be the "widest reaching' system developing intelligence from computer networks", allowing "analysts to search with no prior authorization thorough vast databases containing emails, online chats and the browsing histories of millions of individuals". According to its developers XKeyscore tracks "nearly everything a typical user does on the internet" (Greenwald 2013).

2 Fuchs (2013) for instance argues that "[high-tech surveillance will never be able to stop terrorism because most terrorists are smart enough not to announce their intentions on the Internet".
} 
vealed this year, as well as the justifications offered by policy-makers and law enforcement agencies, have taken place in a wider "ideological atmosphere" 3 that is already receptive to such policies. By ideological atmosphere I mean an atmosphere where a certain idea has become naturalised, meaning neither its origins, nor its validity, are any longer questioned. The idea that seems to have become naturalised here is the existence of a threat to our way of life that requires the policing through surveillance mechanisms. The first task of this paper is to shed light on some of the factors that would contribute to such an ideological atmosphere, namely the ways in which surveillance technology such as CCTV is marketed to the public by corporations and justified by the state.

The second aim of this paper is to help mount a critique of this surveillance ideology. Thus I will examine some theoretical arguments and concepts that so far have been outside the remit of critical studies of ICTs but which are nevertheless useful for a critique of the surveillance ideology. Ideology critique has traditionally been faced with the problem of how to critique ideological language when it must rely on language itself. I will thus begin by briefly examining the concept of ideology itself as "one of those philosophical terms that has entered into everyday speech with an impoverished meaning" (Kotsko 2012), as well as the connection between ideology and language in order to understand the linguistic mechanisms employed by the surveillance ideology. I will then examine the contribution the philosophy of the German thinker Martin Heidegger can make to existing critical approaches to language by philosophically grounding a critique of the surveillance ideology. Critical studies have to date largely avoided engaging with the thinking of this $20^{\text {th }}$ century philosopher due to his tarnished political biography ${ }^{4}$, but this paper argues that his work should not be overlooked as it can offer a valuable insight into the relationship between language and social reality, which is key to understanding how ideology works.

\section{Ideology, Language and Critique}

"Ideology has never been so much in evidence as a fact and so little understood as a concept as it is today... For some, the concept now seems too ubiquitous to be meaningful; for others, too cohesive for a world of infinite difference." (Eagleton 1991, back cover)

Ideology-critique needs to know how ideology works if it wants to be effective. Various definitions of ideology exist but our common understanding of it is rooted in Karl Marx's critique of capitalism. It is important to situate this understanding of ideology within its historical context to understand the form ideology-critique has since taken. For Marx, ideology was a means of maintaining the capitalist social order by blinding the proletariat to the true conditions of their existence. The basis for this materialist account of ideology lies in The German Ideology, where Marx and Engels argued that "the ideas of the ruling class are in every epoch the ruling ideas", and the ruling ideas in turn "nothing more than the ideal expression of the dominant relationships, the dominant material relationships grasped as ideas" ([1846] 1947, 64). For Marx, the consciousness of the individual was determined by his place in the capitalist hierarchy of production. Ideology was thus not a matter of individual consciousness, of the human being as subject. It addressed itself to the consciousness of an entire social class, into which the human being as subject was dissolved. It was here that "false consciousness" ${ }^{5}$, the "distance" or "divergence between so-called social reality and our distorted representation [...] of it" (Žižek 1989, 28) was located.

${ }^{3}$ A number of scholars have remarked on the emergence of a "culture of fear" in Western societies (Furedi 2002 and 2006, Mythen and Walklate 2006, Linke and Smith 2009, Glassner 1999), built upon the increasing profitability of mitigating risk and to legitimize political action in the name of national security and democratic values. As a concept, however, it is not specific to surveillance but includes a range of wider cultural factors, hence I prefer to speak of an ideological atmosphere or the surveillance ideology specifically.

4 Heidegger was a member of the Nazi party and some see in his addresses given as Rector of the University of Freiburg, and in his early work in particular, evidence of his support for Nazi ideology. For one of the most recent as well as nuanced discussions see O'Brien (2010).

${ }^{5}$ As Eagleton argues, there is no evidence that Marx himself used the term "false consciousness" so frequently attributed to him but we find it in a letter written by Engels (Eagleton 1991, 89) 
Because this theory of ideology is one of class and not individual consciousness, it does not answer the question how "the ruling ideas actually get into the heads of individuals and, once there, how effective they might be in securing their acceptance" (Scannell 2007, 203). Various $20^{\text {th }}$ century thinkers have attempted to develop a more nuanced theory of consciousness and ideology than the one Marx provided, these include Georg Lukács and Antonio Gramsci, but it was Louis Althusser who emphasized the specific role of language in shaping individual consciousness. The first question he asked was how precisely the social conditions of production reproduced themselves, the question Marx and orthodox Marxism had "uniquely ignored" (Althusser 1971, 123). How was it that the "tenacious obviousnesses" of these conditions had become so ingrained in our consciousness that it was difficult even to trace their origin (ibid.). Althusser sought to address this blind spot in orthodox Marxism with his concept of the "Ideological State Apparatuses" (ISA), institutions such as the family, the education system, political parties and the media, which operate not through coercion but through ideology. Althusser argued that his concept of the ISA has merely spelled out what Marx had already implied, but the important conclusion he drew was that ideology works not on the consciousness of a class but on that of the individual. The $2^{\text {nd }}$ question was how ideology came to work on individual consciousness. From Althusser's perspective, the consciousness of the individual is secured through his "interpellation", the addressing of the individual, as individual, through language. When an individual responds to a policeman calling "Hey, you there!" by turning around, he is "recruited" as subject and at the same time reproduces the ideology in question. This simultaneity for Althusser is crucial, it is not that there is ideology and then the interpellation of the subject: they are "one and the same thing". Drawing on Lacanian psychoanalysis which argues that there exists no subjectivity outside of language, Althusser's conclusion is that there is no outside of ideology for "ideology has always/already interpellated individuals as subjects" (Althusser 1971,164).

If Althusser is right in claiming that wherever we are in language, we are in ideology, this has some quite serious consequences for the possibility of critique where critique itself must rely on language to express itself. Critique itself depends on the very notion of an outside, a "separate space from which critical reflection can be launched" (Lash 2002, vii), premised, as Eagleton argues, on the Enlightenment belief in the rational human being capable of exerting powers of objectivity from an elevated perspective (1991, xiv). In the introduction I gave some examples of the rhetoric that is part of the surveillance ideology, such as the claim by the former Home Secretary John Reid that the surveillance of all electronic communication is "absolutely essential for effective fighting of terrorism" (Watson 2013). I will consider the rhetoric of the surveillance ideology in more detail in the next section, but the problem we are faced with seems to be how to mount a critique of ideology that relies on language, if we need to utilise these very same tools in order to mount our critique? If we agree that ideology-critique needs an external, transcendental vantage point from which to launch itself, surely we need a different set of tools at our disposal, tools that have not already been co-opted by ideology. But in very practical terms ideology that uses language makes it difficult to occupy this external viewpoint, as it is difficult to critique the rhetoric of the "war on terror", for instance, without using the very expression that we are seeking to dismantle. It seems to be the paradox of ideology that with every attempt to critique it, the object of our critique is reasserted and reinforced by our very utterance of it.

The problem of an outside to ideology has been raised by various critical approaches to language and ideology. Thus Laclau and Mouffe argue that there is no outside to discourse (Laclau and Mouffe 1987) and that the idea of an outside to ideology is the ideological product itself (Laclau 1997). Žižek issues a similar warning, saying that we are never more entrenched in ideology than when we believe ourselves to be outside of it. He argues that "the minimum necessary structuring ingredient of every ideology is to distance itself from another ideology, to denounce its other as ideology. Every ideology does this" (Žižek and Dillworth 2004). What then are the options for critique, and why do we need to add Heidegger's voice to the debate? It has been argued that in the face of the general informational immanence of the Information Age critique has no other option but to be "radically empiricist" (Lash 2002, xii). I would argue, however, that this position is not critique but the surrender of critique and 
that faced with no obvious transcendental vantage point from which to objectively critique ideology, we need to make this very lack the focus of our critique. What I mean is that we need a better understanding of the processes whereby we are put 'in ideology' by language, the process of interpellation itself, and that here Heidegger's philosophy can help us. It allows us to see is how it is our understanding of language as a neutral tool for communication that makes it so amenable to ideology. Language, for us, is something we take for granted, rather than an object of critical reflection. Ideology fully exploits this taken-for-grantedness, but on the other hand a Heideggerian analysis will show how it is that language itself 'interpellates' us before this exploitation can take place. While there might be no outside of language from a Heideggerian perspective a sense of empowerment emerges from critical reflection on this lack of an outside.

\section{What Heidegger Adds to Existing Critical Theories of Language}

Before going into what a Critical Theory of ICTs that seeks to address the surveillance ideology can take from Heidegger's philosophy, a few paragraphs might be useful to help explain my insistence that Heidegger's voice needs to be added to the debate, as the mention of Critical Theory and Heidegger in one sentence will strike some as an odd project. Firstly I want to make it clear that I am not ignoring or pushing out of the way the problems Heidegger's biography has posed for the tradition of Critical Theory. Marcuse was Heidegger's student and his critique of modern, technological societies was deeply influenced by him (Feenberg 2005), though he found it impossible to continue any personal friendship after Heidegger refused to give an apology, public or private, for what was perceived as his open support for Nazism in the 1930s. This problem exceeds the bounds of this paper and is explored elsewhere (O'Brien 2010, or for a highly critical account see Faye 2005) and myself in my thesis (of which the present paper forms part). Here I am following others in exploring Heidegger's ideas on their own merit, areas of concern that other thinkers have shared, notably Jacques Lacan and Jean-Paul Sartre. My argument is not that Heidegger should replace any aspect of Critical Theory, but that his ontology of language and technology offer insights that Critical Theory, and specifically a Critical Theory of ICTs, can employ in these times where the power of critique itself has been questioned (Lash 2002). Heidegger's distinction between an instrumental understanding of language and language's essence sheds new light on why ideology is so eerily at home in language as it shows how language itself structures thought before thought can employ language for a critical purpose. This, for Heidegger, is the essence of language, and I will argue how this helps us understand how the language of the surveillance ideology maintains an ideological atmosphere where there is a need for surveillance.

This understanding of language as in itself ideological calls into question the possibility of a critical language sought by Adorno and Marcuse. For Adorno, Critical Theory was a metalanguage that avoided the "jargon of authenticity" of Heidegger and others. The purpose of Critical Theory is to offer real, viable alternatives to the current historical situation that are within reach of society. Critique, Marcuse argues in One-Dimensional Man, must avoid at all costs the degeneration from political economy to philosophy. But Marcuse saw the limitations of Adorno's theoretical complex, as he saw the inherent contradictions in social reality that provided the foundations for Marx's critique of capitalism in the $19^{\text {th }}$ century neutralised in the 20th. The modern individual, for Marcuse, had come to identify with his situation. The new dream was easily satisfied with consumer goods, from today's perspective we might say an iPad is all it takes to erase desire, and with it the potential for revolution.

So what are the possibilities for critique? From the standpoint from which Marcuse was speaking the Marxist distinction between true and false consciousness still exists, it is only that the individual doesn't see it. The potential of the individual to emancipate himself from his current circumstances (Marcuse believed in the power of individual consciousness over class consciousness) is anaesthetised as he feels no need to change anything about his situation, having become too comfortable with the conveniences of modern life. But there is still an outside perspective from which it is possible to debunk this state of mind as ideology. 
The "critical medium" for Marcuse turned out to be art, as he saw in its illusory nature a greater realism than in ordinary experience "shackled by the constraints of positivism" (Agger 1992, 159). Marcuse, like Heidegger before him, looks to poetry for truth, but there is a crucial difference. Marcuse looks for the critical potential of poetry in the "truth" and "hope" it articulates in its "refusal of the actual" (Marcuse 1969, 34). The ability to convey an alternative social reality makes poetic language a medium for critique, but it is precisely these mediumistic qualities that Heidegger challenges. For Heidegger, poetry, like no other domain of language, celebrates the very materiality of language, its "surface-level superficiality" which shows up the reality-constructing essence of language that is obscured by our everyday, instrumental use of it.

\section{The Language of the Surveillance Ideology}

This section will explore some of the mechanisms that might be contributing to an ideological atmosphere that sustains the surveillance ideology, by looking at some of the ways in which surveillance technology is marketed to the public by corporations and justified by the state. The ubiquity of CCTV in the United Kingdom means the warning signs that point out where they are in use are one of the most prevalent examples of how the promise of security through surveillance manifests itself. The use of CCTV (Closed Circuit Television) in the UK has expanded dramatically over the last two decades: in 1991 no more than ten British cities operated CCTV surveillance equipment in public spaces, and these systems were smallscale and locally funded cooperations between private entities and local police (Norris et al. $2004)^{6}$. Today whole areas of cities are under surveillance and it is estimated that there are now 5.9 million cameras in operation, 1 for every 11 citizens (Barrett 2013). It is argued that "[e]ffective CCTV schemes are an invaluable source of crime detection and evidence for the police" (ibid.). The actual effectiveness of CCTV for these purposes has been questioned, but according to Norris et al. it is beside the point. For politicians, they argue, it is crucial "to be seen to be doing something" and faced with the complexity of problems such as terrorism, "technological fixes which promise the appearance, if not the reality of security are highly appealing" (2004, 126).

The technological equipment itself gives an appearance of security and thus acts as a signifier of the surveillance ideology, but as the cameras are becoming less obvious and easy to spot (Murakami Wood 2011), the legally required warning signs act as effective mediators of the surveillance ideology in lieu of the cameras themselves. They employ discursive mechanisms that indeed promise the appearance of security, but as I aim to show, they do so by sustaining a climate of threat by their very reference to our "safety" and "security". The below are typical examples of the CCTV warning sign, fluorescent yellow and black to attract attention, and featuring a stylised CCTV camera icon. In the the first image, the sign alerts the passerby to the fact that "This organisation operates $24 \mathrm{hr}$ CCTV surveillance" and that "[i]mages are being recorded for the purpose of crime prevention and public safety":

\footnotetext{
${ }^{6}$ Norris et al. (2004) trace the rise of CCTV in Britain in comparison with the global rise in CCTV surveillance.

7 Krahmann (2011) for instance argues that due to the poor quality, complexity and sheer amount of recorded material CCTV is effectively useless as a deterrence mechanism. A European-wide review commissioned by the European Union's Directorate General for Internal Policies urges to treat arguments promoting the use of CCTV for crime-prevention with caution (Statewatch 2009).
} 


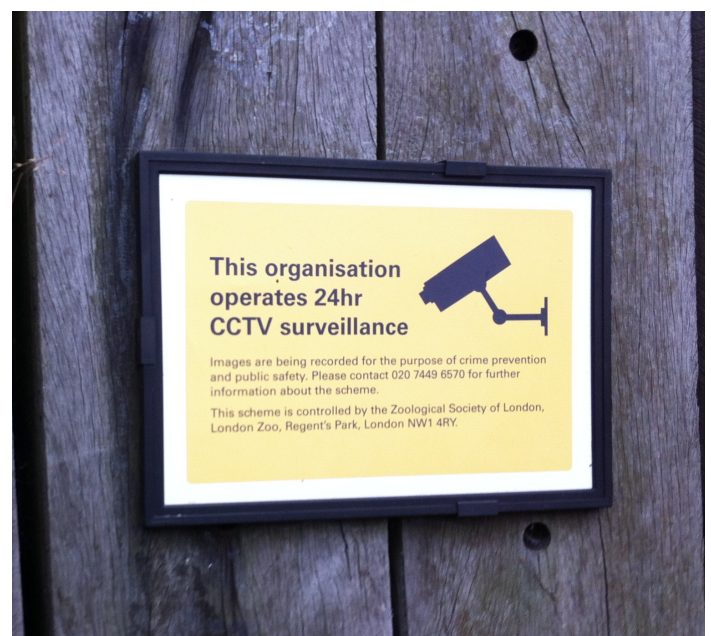

Figure 1: CCTV warning sign outside London Zoo, image courtesy of Chris Campbell.

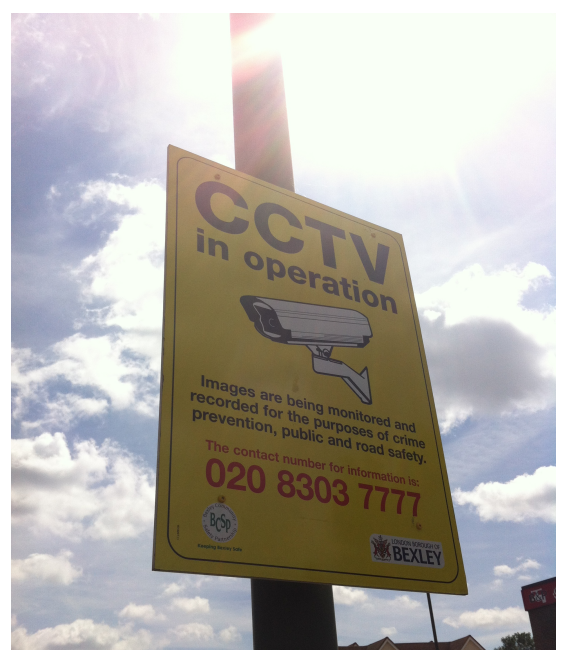

Figure 3: CCTV warning sign in Bexley, London, image courtesy of Chris Campbell.

The sign in the second image contains the warning: "CCTV in Operation. Images are being monitored and recorded for the purposes of crime prevention, public and road safety". Other typical noticications are " $24 \mathrm{hr}$ CCTV - Images are being recorded and monitored for your safety and to help prevent crime" or, more frequently in semi-public or privately owned spaces such as shops, "Warning. CCTV security in operation on these premises". In train stations or airports announcements are frequently made via load speakers, however they also emphasise that surveillance is taking place for the purposes of "safety and security".

The below is a preliminary attempt to model the discursive mechanisms employed by the surveillance ideology, specifically the relationship between the rhetoric used justifications of surveillance and the surveillance process itself. At the centre of the model is the surveillance process itself. The surrounding circles contain examples of the rhetoric used by industry and governmental actors in their justifications of surveillance, such as "security", "crime prevention" or "efficiency". This rhetoric works similar to the light-reflective strips on a cyclist's clothing, deflecting from the surveillance process itself towards the prospective bene- 
fits of "security" or "crime prevention". Thus the rhetoric of the surveillance ideology forms a kind of "ideological packaging' ${ }^{8}$ around the technologies and the surveillance process itself.

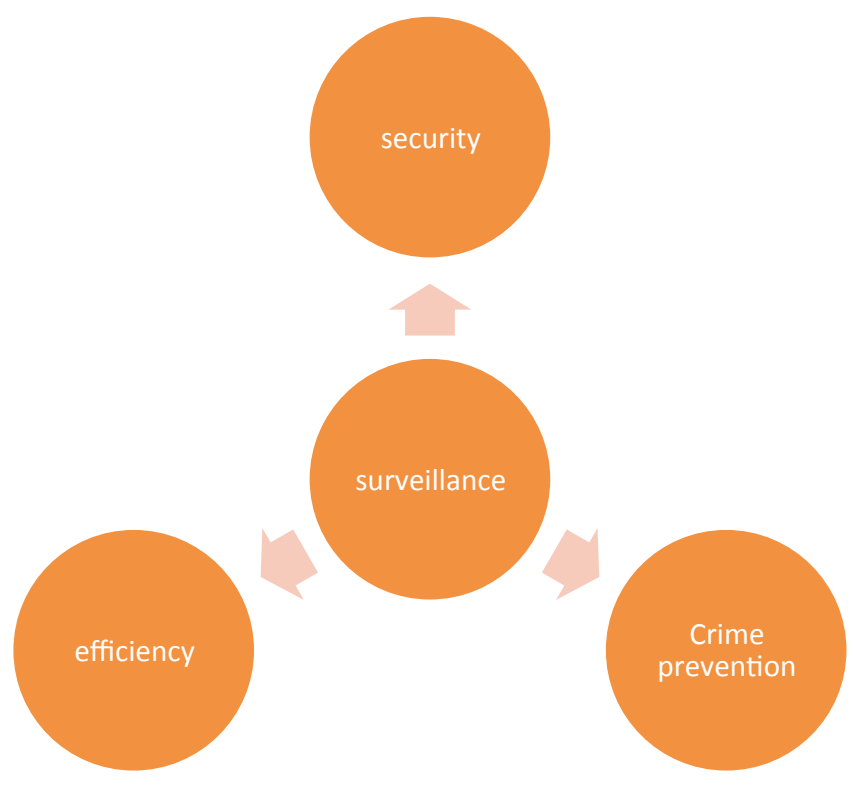

Figure 2: The Ideological Packaging of ICTs

Arguably, however, the mechanisms of this ideological packaging by which words such as "security" and "convenience" are attached to the surveillance process are not yet fully understood. I would argue that this process is far more complex and significant than existing definitions of ideology would permit, as it is rooted in the ontological relationship between language and being. This is the relationship that Heidegger will help us understand. From his perspective the history of Western thinking has obscured this relationship, which, as I hope to show over the following pages, has significant implications for ideology: the effectiveness of the surveillance ideology is largely indebted to an instrumental understanding of language whereby words transparently envelop a piece of reality, thus making it communicable. The consequence of this is that we take the rhetoric of "safety" or "crime prevention" to be statements of actual fact rather than realities "called into being" by their verbalisation. This, for Heidegger, is the essence of language which its instrumental everyday use has obscured.

\section{The Instrumental Ideology of Language}

As I have argued, Heidegger is not a name that is frequently mentioned in debates about ideology and ideological language. Even the branch of philosophy dedicated explicitly to the study of language, which developed in the second half of the $20^{\text {th }}$ century based on the work of John Searle, contains very little in terms of reference to Heidegger. In short so far there has been no obvious Heideggerian angle to the connection between ideology and language, but in the following paragraphs I aim to show how his philosophy provides the very ontological basis for this connection. Critical and psychoanalytically inspired approaches to language emphasise how language provides the grounds for experience but don't explain the ontological relationship that language has to being itself. For Heidegger the "essence of language" is how the addressing of a thing through language brings the thing itself into being, but he argues that our everyday use of it has obscured this essential property of language. In our everyday use of language, language has a transparent quality and only serves to communicate a

\footnotetext{
${ }^{8}$ The concept of the "ideological packaging" was first presented in a joint paper "The Ideological Packaging of ICTs" given at the $4^{\text {th }}$ ICTs \& Society Conference in Uppsala, Sweden, in May 2012.
} 
factual, external reality. Hence the "security" rhetoric that pervades the surveillance ideology is accepted as the herald of an actual threat, as we are about to see.

Western philosophy, Heidegger acknowledges, has a long-standing and natural preoccupation with language. After all, language has historically defined what it is to be human, it is "as one who speaks that man is - man" (Heidegger 1971, 187). But from his perspective, scientific interest in language has not sufficiently challenged our everyday, instrumental use of it. At worst, it has even served to reinforce the instrumental ideology. Logical positivism, drawing on both Bertrand Russell and Ludwig Wittgenstein's work on logic and language, takes a view of language that is "descriptive of a reality that is outside, external to language" (Scannell 2007,172). The main question was whether a sentence could be said to be true, or not. For Heidegger, this conception of truth as correspondence however, was one of the original errors of Western philosophy. Truth, for Heidegger, is not the correspondence of one state of affairs with another but the bringing of things into the open from hiddenness, to show something as it really is, what he refers to as unconcealment. What we take as truth is merely correctness. Truth, however, is precisely the function of language. Hence, the Western philosophical tradition has led us to the wrong conclusions about language, this most natural of phenomena, for they "ignore completely the oldest natural cast [Wesensprägung] of language [...] despite their antiquity and despite their comprehensibility, they never bring us to language as language" (Heidegger 1971a, 191).

Put simply, being brought to "language as language" means forgetting what Western philosophy has taught us about language and instead experiencing it. The essence of language, as Heidegger argues, lies in its primordial experience, obscured by centuries of talking about and using language have obscured. Language, for Heidegger, is not a tool at our disposal, but something that is infinitely more powerful, something that discloses or unlocks being itself. His project is to challenge the instrumental ideology of language, as it is this understanding of language as a neutral carrier for meaning that blinds us to its essence. As a first step the following paragraphs trace this instrumental ideology of language and show how within the current surveillance ideology it is responsible for words such as "security" being taken as neutral envoys of a reality outside of language. The second step will be to examine the essence of language obscured by its instrumental use, that is, the ontological relationship between the word and the thing. From Heidegger's perspective this is the key to the surveillance ideology as the essence of the word "security" lies in the calling into being of the threat that is needed to justify surveillance measures such as those recently revealed by Edward Snowden.

The instrumental ideology of language is rooted first and foremost in its everydayness: "Man speaks. We speak when we are awake and we speak in our dreams. We are always speaking, even when we do not utter a single word aloud, but merely listen or read, and even when we are not particularly listening or speaking but are attending to some work or taking a rest. We are continually speaking in one way or another" (Heidegger 1971a, 187). Conventionally, language is thus defined as either "the activation of the organs for sounding and hearing" or the "audible expression and communication of human feelings [and] [...] thoughts" (Heidegger 1971a, 190). From every angle these definitions will strike us as correct: if we observe someone speaking, we see him opening his mouth to shape the words, our ears can hear the sound his words make, and our brains enable us to process information, hence we are able to translate the sound our ears absorb into meaning, allowing us to respond. We assume that what we hear are the thoughts and feelings the person speaking intended to communicate.

Heidegger doesn't deny this is how we commonly experience language, but he challenges us to question the assumptions that underlie this commonsensical understanding. It asserts that speaking is an act of expression. "The idea of speech as an utterance is the most com-

\footnotetext{
${ }^{9}$ Against the accusation made by Feenberg (1999) that Heidegger's thinking lacks concreteness, I would argue that Heidegger is in fact concerned with how to understand what is given, how to understand the way we experience the world around us. What might strike the reader as an obsessive interest in the banal is in fact directed towards unearthing the experience that precedes theorization. Thus his starting point is always the obvious that escapes all conventional theoretical considerations.
} 
mon" (Heidegger 1971a, 190, emphasis added). But Heidegger points out that this assertion "already presupposes the idea of something internal that utters or externalizes itself" (ibid, emphasis added. $)^{10}$. Secondly, it asserts without doubt that speech is an "activity of man. Accordingly we have to say that man speaks". By insisting on this order we are already negating the possibility that "[i]t is language that first brings man about" (Heidegger 1971a, 190) - the argument of psychoanalysis. Finally we have the assertion that "human expression is always a presentation and representation of the real and the unreal" (ibid.). This too is correct, since we can talk about an actual object, such as a painting at a gallery, but at the same time we can talk about a dream we have had about this very painting. Speech stands in a relationship to the world, both to that of actually existing objects and our imagination. The view of language put forward by its definition as an utterance, an activity of man and a representation of an external/internal reality "conforms to what an investigation of linguistic phenomena can make out in them at any time" (ibid.). The problem for Heidegger is that we never questioned the "singular role" played by these "correct ideas" about language. What is it that makes its way through language into the world? Whence do we confidently undertake this separation between inner, outer and language? Does this not somehow presuppose that language acts as a neutral vehicle or mode of transportation, with the sole purpose of conveying something that exists independently of its verbalisation, in the most accurate possible way, without interference and without adding something that wasn't there in the first place? Language, our commonplace understanding suggests, dresses an external or internal reality in words. This "instrumental ideology of language" is the reason we take words such as "safety" and "security" for granted as transmitting a factual reality that exists independently of its expression through language.

So from Heidegger's perspective the view of language as fundamentally "fact-stating" and "descriptive" (Scannell 2007, 172) is not just to be found in the logical positivist approaches to language based on Russell and Wittgenstein, it determines our everyday understanding and use of it. The speech act theory that developed in the 1960s through the work of J.L. Austin is often said to have challenged this approach and set philosophy of language on a new course by emphasising the constructivist power of the spoken word. But outside the power the "speech act" or utterance had to shape a social situation (e.g. the act of a priest of pronouncing a couple "husband and wife") it still posited the existence of an external, objective realm of language where truth was not determined by the situation but transcended it. This is an idea psychoanalytical approaches to language such as that of Althusser would negate, and Heidegger too would deny the existence of such an outside, transcendental realm of language. Talking about language still involves language, hence there is a circularity that is inevitable and Heidegger doesn't exempt himself from it. But being aware of this circularity is the first step towards a non-instrumental understanding of language and ultimately brings us a step closer to what Heidegger claims is its essence.

\section{Truth and the Essence of Language}

The approaches to language discussed here, whether they were concerned with language as ideology (Althusser), or the philosophy of language (whether logical positivist or constructivist), relate language with truth. Truth seems to be the opposite of ideology. For Heidegger, the essence of language is indeed a matter of truth, but he doesn't equate truth with an external, objective meaning that language must strive to convey, nor is it something that is forever outside of language and unreachable. Truth, for Heidegger, is the essence of language itself, the relationship between the word and the thing, but not in the way this relationship has conventionally been understood, where the word is a correct representation of the thing. As he puts it, it is "language alone [that] brings what is, as something that is, into the Open for the first time [...] Language, by naming beings for the first time, first brings beings to word and to appearance. Only this naming nominates beings to their being from out of their being"

\footnotetext{
10 "Expression" and "utterance" already contain within themselves a movement from within to the outer - "expression" containing the Latin prefix "ex", meaning "out of" or "from within", and "utterance" deriving from the Middle Low German "utern", meaning "to turn out", "to show" and "ut" meaning "out".
} 
(Heidegger 1971c, 71, emphasis in the original). What Heidegger is trying to explain is that language is not merely a talking about beings, but that we call beings into being by addressing them through language.

For Heidegger, the idea of truth as the correspondence of a representation with the "true state of affairs", or a verifiable attribute of something such as what we can "make out" about language by observing speech, is one of the original errors of Western philosophy. Ever since Plato, he argues, philosophy has taught us to think of truth in terms of correspondence (Gunkel and Taylor forthcoming), but we have confused truth with correctness. Instead, he argues, "[i]f we translate á $\lambda \hat{\eta} \theta \varepsilon$ Ia [aletheia] as "unconcealment", this translation is not merely more literal; it contains the directive to rethink the ordinary concept of truth in the sense of the correctness of statements and to think it back to that still uncomprehended disclosedness and disclosure of beings" (Heidegger 2008, 125, emphasis added). The implications of this distinction Heidegger draws between truth and correctness are profound. Firstly, our obsession with the "correspondence theory of truth" (what he calls "correctness") means we have a tendency to fetishise the "accurate representation" of facts over any underlying deeper meaning. This ties in with the general instrumentality of thought that for Heidegger is the culmination of Western metaphysics in the rationality of technological modernity.

By way of illustration we might consider the example of the body scanners implemented at a number of airports worldwide - as technologies collecting and processing data in digital form they too form part of the move towards ubiquitous surveillance. In the UK Manchester Airport came under severe scrutiny by privacy advocates during their trial of body scanners that used x-ray technology to scan through passenger clothing. When the European Commission failed to approve continued use of the scanners after the trial period had ended, Manchester announced it would begin using "privacy-friendly", "non-invasive" scanning equipment that would merely produce cartoon images of the passenger's body (BBC News 2012). While the new technology might indeed produce a less accurate image of the body (in so far the argument for greater privacy may be correct), the use of terminology such as "privacy-friendly" or "non-intrusive" ignores the fact that the scanning process as such represents an invasive procedure as the human is subjected to surveillance by a machine with no knowledge about what happens with the images once collected. So while we adhere to our conventional understanding of the connection between language and truth, we might assemble everything that is correct, but fail to realise the full significance of what is being said.

There is another, potentially even more significant implication of the distinction between truth and correctness. More specifically this is an implication of interpreting truth "correctly" (pardon the pun) as "unconcealment". If we accept Heidegger's argument that truth is not a statement corresponding to a state of affairs but a state of disclosedness, a state where things are revealed as what they really are, then the essence of language is to reveal the true nature of the thing it addresses. Put more simply, language is not a talking about things that already exist independently by themselves, but it is through language that things approach us. The spatial dimension of approaching is crucial, because what Heidegger is trying to explain in necessarily abstract terms is that language doesn't merely "put into words" (though we often use this expression), it calls into being from a distance and thus brings what is being called closer to us. This, for Heidegger, is the ontological relationship between the thing and the word that lies at the heart of the essence of language, and it can help us understand how it is possible that talk of "safety" and "security" maintains the need for surveillance it is through these concepts that the reality of a threat approaches us. In order to fully understand how language calls into being we need to follow Heidegger on a slightly odd track, one that takes us through poetry, which he sees as "the domain that most heeds the insight that language is not simply a tool for making communicable an objective external reality" (Gunkel and Taylor forthcoming). 


\section{Calling the Threat}

“...and what are poets for in a destitute time?" (Hölderlin quoted in Heidegger 1971e, 89)

Like for Marcuse, poetry for Heidegger has a special place amongst all other forms of language and for both thinkers it is poetry that is most intimately connected with truth. Marcuse looks to poetry for its refusal of the actual historical situation and its ability to imagine an alternative reality. He sees in it a medium for critique after critical potential has been neutralised in close to all other domains of social life. Heidegger has often been branded as a Luddite "who would like to return from the exploitation of the earth, consumerism, and mass media to the world of the pre-Socratic Greeks or the good old Schwartzwald peasants" (Dreyfus $1995,26)$ and his preoccupation with poetry might suggest that he too sees the only possibility for truth and redemption from the onslaughts of modern technology in the realms that transcend mortal existence, in faith or in art. I think this is a misreading of Heidegger, but one which unfortunately the space constraints of this paper won't allow us to go into. But in Marcuse's hope of poetry as a critical medium an element of instrumentality seems to remain, where for Heidegger the point of poetry is its very non-instrumentality, its very "surface-level materiality" (Gunkel and Taylor forthcoming). Heidegger is not so much concerned with the issue of "human solitude" in Georg Trakl's poem "A Winter Evening", but with how the language of poems calls this solitude into being.

So there is no need to reproduce the lines of "A Winter Evening" in full, the point is that the window against which the snow is falling, and the tolling of the vesper bell that both feature in Trakl's poem, do not address or "cloak" an existing window or tolling bell with words, but both are brought before us by their very naming as the "[w]indow with falling snow arrayed," and the "vesper bell" that "[l]ong tolls". In Heidegger's own words: "Does [...] [naming] deck out the imaginable familiar objects and events - snow, bell, window, falling, ringing - with words of a language? No. This naming does not hand out titles, it does not apply terms, but it calls into the word" (Heidegger 1971a, 196). What Heidegger means is that our naming of things is not merely an attaching of an array of letters and sounds to a thing, whether that thing is concrete like a bell or abstract like the sound of its ringing. Rather, our naming of these things brings them towards us from a distance, it is a naming that "calls", and as Heidegger reminds us, calling always "brings closer what it calls" (ibid.).

The misunderstanding that we must avoid, however, is to think that by calling something we might be bringing this thing into our presence. Heidegger is emphatic that this is not the case: what we have called, or summoned, into closeness from a distance at the same time remains in this distance. Distance and closeness interact in everything that we call and thus retain the true being of the thing we have called. The difference between closeness and presence is not easily retained in the English translation: things presence in their call, but they do not become a presence. In the original German "sie wesen an" (they presence), "wesen" has the same etymological root as "das Wesen", the essence of things. The English translation "presence"/"essence" however misses this reference which conveys that our calling of things into presence lets us experience them in their essence. It is crucial that we understand this correctly because in the context of the surveillance ideology the rhetoric of "security" and "crime prevention" does not actually cause the threat to our security to become a presence. The point is that the "calling from a distance" of the threat is enough to legitimise the surveillance process. The ideological atmosphere within which surveillance has become near-ubiquitous is in fact the "calling from a distance" of a threat that emanates from the language of "safety and security".

Psychoanalytic theory argues that desire lives from the distance between its actualisation and its symbolization (Žižek 1989). Heidegger's inquiry into the essence of language suggests that the threat around which the surveillance ideology is based functions in the same way. It taps into the distance that exists between the thing and the word that calls it into being, the symbolisation of the threat in a CCTV warning sign and the actual terror or criminal event. The individual is never confronted with the event itself, nevertheless the surveillance 
ideology turns him from a citizen with rights and liberties into a prospective victim in need of protection and more likely to accept surveillance as part of these protective measures.

\section{Conclusion}

In the context of the move towards "ubiquitous surveillance" (Murakami Wood 2011) that the recent revelations of global surveillance programmes have again manifested, this paper has emphasized the need for Critical Theory to question the extent and nature of these surveillance processes. This paper has aimed to contribute to this process of interrogation, by focusing on what Fuchs (2013) has termed the "surveillance ideology", the promise of security through surveillance that seeks to legitimize the infringement of our civil liberties that result from increasingly comprehensive surveillance. Two aims were identified at the beginning of this paper, firstly to cast some light onto the workings of the surveillance ideology itself, and secondly, to contribute some theoretical groundwork for a critique of the surveillance ideology drawing on the work of Martin Heidegger. In order to locate the gap in existing critical approaches to language and ideology that Heidegger can fill I began by examining the concept of ideology and the connection between ideology and language. Althusser corrected the blind spot of orthodox Marxism by identifying language as the process whereby the individual, as opposed to the social class, becomes an ideological subject, but seemed to offer no account of how language operates at the most basic, ontological level. Consequently there seemed some justification to look to Heidegger's account of language for an explanation that might yield a better understanding of the linguistic mechanisms employed by the surveillance ideology.

In order to gain an understanding of how the surveillance ideology works I have examined some of the ways in which surveillance technology such as CCTV is marketed to the public by corporations and justified by the state. My discussion of examples of this rhetoric, such as the arguments made by political actors and the ubiquitous CCTV camera warning signs has shown that the surveillance ideology rests on the continued emphasis on "safety and security". Approached through Heidegger's philosophy of language, this rhetoric seizes to justify the need for protective measures but becomes its source. Heidegger's analysis highlights how the history of Western philosophy has fostered an everyday use of language that is instrumental, and it is this instrumentality that inclines us to accept the rhetoric of "safety and security" as a neutral envoy of a threat that exists beyond and outside of language itself. For Heidegger, however, language in its very essence is non-instrumental, it is not the neutral communication of an external reality, but the calling into being of reality itself. Through a Heideggerian analysis of the ontological relationship between the security rhetoric and the actual criminal or terror event, it emerges how the threat necessary to sustain the surveillance ideology is created.

The second aim of this paper was to help mount a critique of this surveillance ideology. The possibility of mounting a critique of ideological language, as we have seen, is complicated by the fact that critique must rely on language itself. The question is whether Heidegger's philosophy offers a route out of this "vicious circle" where other thinkers have argued that an outside perspective from which to engage in ideology-critique doesn't exist, or that only "radical empiricism" will do. Heidegger doesn't offer a solution to the problem of an outside to language, indeed his argument only confirms Althusser's claim that wherever we are in language, we are in ideology. From Heidegger's perspective too language interpellates us even before ideological institutions have the chance to co-opt it and use it for their purposes. However, this perspective should not be confused with resignation. Rather, critique must draw on thought itself, on the reflection on the constraints that language poses upon us. Thus Heidegger is not preoccupied with poetry for its promise of an alternative social reality but because it challenges the instrumentality of language that ideology exploits. In poetry we find in its clearest form the conspicuousness of language that Heidegger insists it possessed from the beginning, but that through more than two millennia of instrumental thinking we have lost. What this means in terms of the surveillance ideology is that the rhetoric of "safety and security" needs to become conspicuous. This is first and foremost a matter of aware- 
ness, of critical thinking. But as Žižek recently commented on Marx's famous criticism that philosophy only ever interprets the world (Thesis 11 on Feuerbach, Marx and Engels [1846] $1947,123)$, "in the $20^{\text {th }}$ century, we maybe tried to change the world too quickly, the time is to interpret it again, to start thinking" (Žižek 2012).

\section{References}

Agger, Ben. 1992. The Discourse of Domination: From the Frankfurt School to Postmodernism. Evanston: Northwestern University Press.

Althusser, Louis. 1971. Ideology and Ideological State Apparatuses. In Lenin and Philosophy and Other Essays, 121-173. London: NLB.

Barrett, David. 2013. One Surveillance Camera for Every 11 People in Britain, Says CCTV Survey. The Telegraph. July 10, 2013. Accessed October 14, 2013. http://www.telegraph.co.uk/technology/10172298/One-surveillance-camera-for-every-11people-in-Britain-says-CCTV-survey.html

BBC News. 2012. Manchester Airport's Body Scanners Scrapped. Accessed July 17, 2013. http://www.bbc.co.uk/news/uk-england-manchester-19620981

Dreyfus, Hubert. 1995. Heidegger on Gaining a Free Relation to Technology. In Technology and the Politics of Knowledge, es. Andrew Feenberg and Alastair Hannay, 97-107. Bloomington: Indiana University Press.

Eagleton, Terry. 1991. Ideology. London: Verso.

Feenberg, Andrew. 1999. Questioning Technology. London: Routledge.

Feenberg, Andrew. 2005. Heidegger and Marcuse: The Catastrophe and Redemption of History. London: Routledge.

Fuchs, Christian. 2013. PRISM and the Social Media-Surveillance-Industrial Complex. Accessed July 3, 2013 http://fuchs.uti.at/920/

Furedi, Frank. 2002. Culture of Fear: Risk-Taking and the Morality of Low Expectation. London; New York: Continuum.

Furedi, Frank 2006. Culture of Fear, Revisited. London; New York: Continuum.

Glassner, Barry. 1999. The Culture of Fear: Why Americans are Afraid of the Wrong Things. New York: Basic.

Greenwald, Glen. 2013. XKeyscore: NSA tool collects 'nearly everything a user does on the internet'. Accessed August 1, 2013. http://www.theguardian.com/world/2013/jul/31/nsa-top-secret-program-online-data

Gunkel, David, and Paul Taylor. Forthcoming. Heidegger and the Media. Cambridge: Polity Press.

Heidegger, Martin. 1971b. ...Poetically Man Dwells... In Poetry, Language, Thought, translated by Albert Hofstadter, 209-227. New York: HarperCollins.

Heidegger, Martin. 1971a. Language. In Poetry, Language, Thought, translated by Albert Hofstadter, 185-208. New York: HarperCollins.

Heidegger, Martin. 2008. On the Esssence of Truth. In Basic Writings, ed. by David Farrell Krell. Toronto: Harper Perennial.

Heidegger, Martin. 1971c. The Origin of the Work of Art. In Poetry, Language, Thought, translated by Albert Hofstadter, 15-86. New York: HarperCollins.

Heidegger, Martin. 1971e. "What Are Poets For?" In Poetry, Language, Thought, translated by Albert Hofstadter, 87-140. New York: HarperCollins.

Kotsko, Adam. 2012. How to Read Žižek. Accessed May 15 ${ }^{\text {th }}, 2013$. http://lareviewofbooks.org/article.php?id=897\&fulltext=1

Krahmann, Elke. 2011. The Commodification of Security in the Risk Society. Accessed October 10, 2013.

http://citation.allacademic.com/meta/p_mla_apa_research_citation/2/5/1/9/0/pages251908 /p251908-1.php

Laclau, Ernesto. 1997. The Death and Resurrection of the Theory of Ideology. MLN 112 (3): 297-321 
Laclau, Ernesto and Chantal Mouffe. 1987. Post-Marxism without Apologies. New Left Review 1 (166):79-106.

Lash, Scott. 2002. Critique of Information. London: Sage, 2002.

Linke, Uli and Danielle Smith. 2009. Cultures of Fear: A Critical Reader. London and New York: Pluto Press.

Marcuse, Herbert. 1969. An Essay on Liberation. London: Allen Lane/Penguin.

Manchester Airport. 2013. Body Scanners. Accessed July 17, 2013 http://www.manchesterairport.co.uk/manweb.nsf/Content/X-Ray-Scanners-PublicInformation

Marx, Karl and Friedrich Engels. [1846] 1947. The German Ideology. London: International Publishers.

Murakami-Wood, David. 2011. Vanishing Surveillance: Why Seeing What is Watching Us Matters. Accessed July 30, 2013. http://www.priv.gc.ca/information/research-recherche/2011/wood 201107 e.asp

Mythen, Gabe, and Sandra Walklate. 2006. Communicating the Terrorist Risk: Harnessing A Culture of Fear?" Crime, Media, Culture, 123-142.

Norris, Clive et al. Editorial. 2004. The Growth of CCTV: A Global Perspective on the International Diffusion of Video Surveillance in Publicly Accessible Space. Surveillance \& Society $2(2 / 3): 110-135$.

O'Brien, Mahon. 2010. Re-Assessing the 'Affair': The Heidegger Controversy Revisited. The Social Science Journal 47 (1): 1-20.

Scannell, Paddy. 2007. Media and Communication. London: Sage.

Statewatch. 2009. A Review of the Increased Use of CCTV and Video Surveillance for Crime Prevention Purposes in Europe. Review conducted for the Directorate General Internal Policies of the European Union. Accessed September 19, 2013. http://www.statewatch.org/news/2009/apr/ep-study-norris-cctv-video-surveillance.pdf

Watson, Steve. 2013. British Ministers call for Mass Government Snooping in Wake of Woolwich Attack. Infowars. May 23, 2013. Accessed October 3, 2013. http://www.infowars.com/british-ministers-call-for-mass-government-snooping-in-wake-ofwoolich-attack/

Žižek, Slavoj. 1998. The Sublime Object of Ideology. London; New York: Verso.

Žižek, Slavoj. 2012. Don't Act. Just Think: Transcipt. http://bigthink.com/videos/dont-act-just-think (accessed August 28, 2013).

Žižek, Slavoj, and Dianna Dillworth. 2004. The Believer. Accessed May 17, 2013. http://www.believermag.com/issues/200407/?read=interview_zizek

\section{About the Author}

Heidi Herzogenrath-Amelung

Heidi Herzogenrath-Amelung is a Doctoral Researcher at the Institute of Communications Studies, University of Leeds and Senior Lecturer in Communication Theory at the University of Westminster, London. Her PhD research focuses on how Martin Heidegger's philosophy of technology can be harnessed for a Critical Theory of ICTs. She has co-founded and coordinated research networks on surveillance and critical approaches to ICTs. 